\title{
WestVirginiaUniversity
}

THE RESEARCH REPOSITORY @ WVU

Graduate Theses, Dissertations, and Problem Reports

2016

\section{Protecting the Shield: How the NFL frames an organizational crisis}

Mel Anton

Follow this and additional works at: https://researchrepository.wvu.edu/etd

\section{Recommended Citation}

Anton, Mel, "Protecting the Shield: How the NFL frames an organizational crisis" (2016). Graduate Theses, Dissertations, and Problem Reports. 5115.

https://researchrepository.wvu.edu/etd/5115

This Thesis is protected by copyright and/or related rights. It has been brought to you by the The Research Repository @ WVU with permission from the rights-holder(s). You are free to use this Thesis in any way that is permitted by the copyright and related rights legislation that applies to your use. For other uses you must obtain permission from the rights-holder(s) directly, unless additional rights are indicated by a Creative Commons license in the record and/ or on the work itself. This Thesis has been accepted for inclusion in WVU Graduate Theses, Dissertations, and Problem Reports collection by an authorized administrator of The Research Repository @ WVU. For more information, please contact researchrepository@mail.wvu.edu. 


\title{
Protecting the Shield: How the NFL frames an organizational crisis
}

\author{
Mel Anton \\ Thesis submitted \\ to the Eberly College of Arts and Sciences \\ at West Virginia University \\ in partial fulfillment of the requirements for the degree of \\ Master of Arts in \\ Sociology
}

Joshua Woods, Ph.D., Chair

Katie Corcoran, Ph.D.

Lawrence Nichols, Ph.D.

Departments of Sociology and Anthropology

Morgantown, West Virginia

2016

Keywords: organizations, impression management, framing, accounts, NFL, football, concussions

Copyright 2016 Mel Anton 


\title{
ABSTRACT
}

\section{Protecting the Shield: How the NFL frames an organizational crisis}

\begin{abstract}
Mel Anton
The National Football League (NFL) is a multi-billion-dollar organization that is constantly utilizing impression management techniques to craft its public image. Currently, the NFL is embroiled in what many refer to as the "concussion crisis." When the NFL discusses this issue, one of the most common impression management techniques used is framing and accounts. This research brings together these two concepts to study this issue. I have analyzed a sample of press releases from the NFL using qualitative content analysis. From this, I have found and defined some common frames used, when they are used, and then used accounts research to determine why. The purpose of this study is to detail how the NFL uses organizational impression management strategies, while also extending both the framing and accounts literature.
\end{abstract}




\section{Table of Contents}

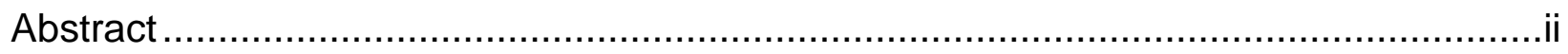

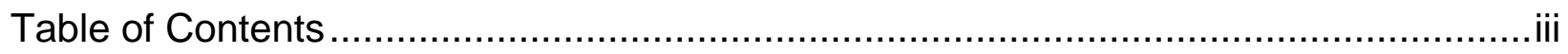

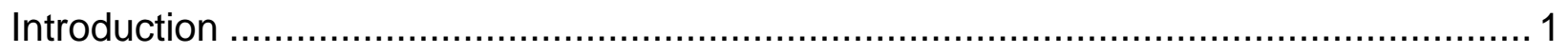

I. Chronic Traumatic Encephalopathy (CTE) and its impact on the NFL ................ 3

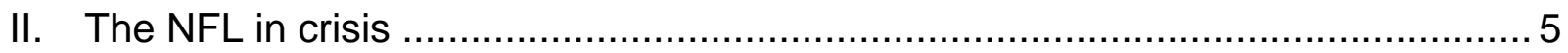

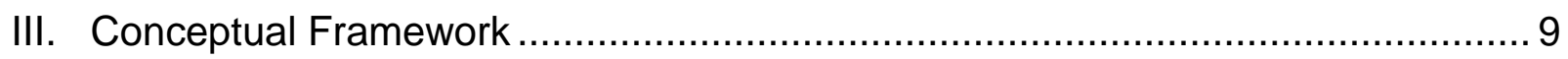

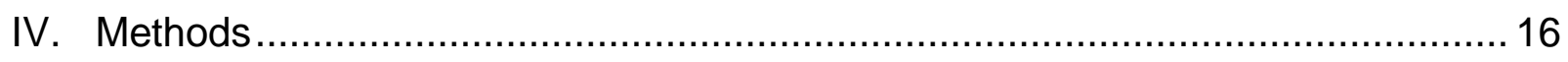

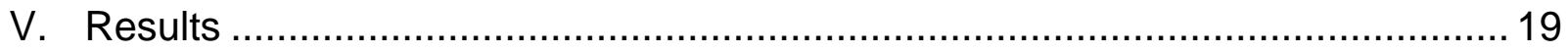

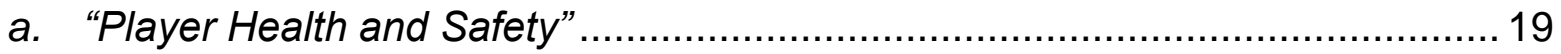

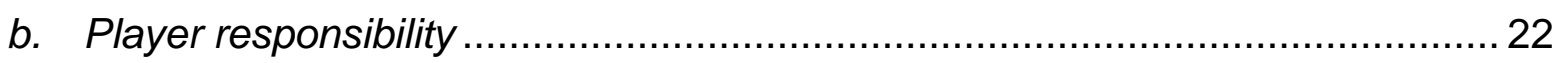

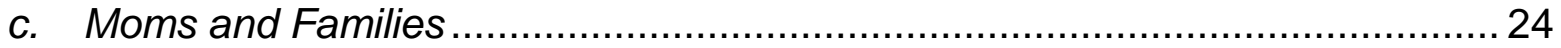

d. Not Just a Football Problem .................................................................... 26

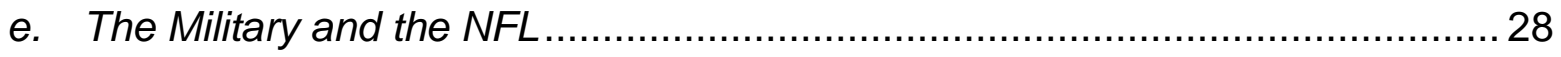

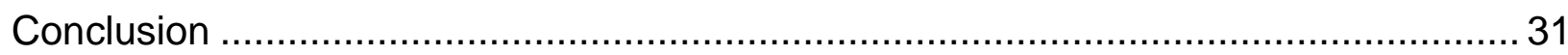

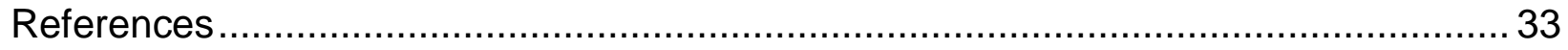

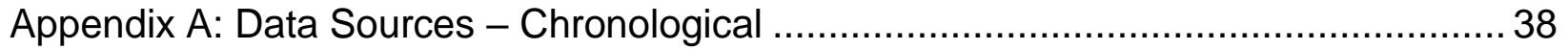




\section{Introduction}

It is May $9^{\text {th }}, 2014$ when inside linebacker Chris Borland gets the call. He's been selected in the third round of the NFL draft, $77^{\text {th }}$ overall, by the San Francisco 49ers (Price, 2014). After honing his skills for five seasons at the University of Wisconsin, he has finally made it to the pros (Price, 2014). Less than one year later he walks away from the fame, the glory, and a $\$ 2.93$ million contract citing concerns of head trauma (Fucillo, 2014; Hanzus, 2015). He is 24 years old.

Professional football is the most popular sport in the United States. In 2013, 46 of the 50 most watched sporting events were National Football League (NFL) games (Paulsen, 2013). Professional football is also the most profitable sport in the United States. According to Forbes, the average NFL team is worth $\$ 1.43$ billion (Ozanian, 2014). In comparison, the average Major League Baseball (MLB) team is worth $\$ 811$ million, and the average National Basketball Association (NBA) team is worth only $\$ 634$ million (Ozanian, 2014). To be able to stay popular and profitable, the NFL needs buyers and those buyers are fans. To ensure NFL fans continue to buy, the NFL employs various impression management strategies, especially in the case of an organizational crisis.

An organizational crisis is a "specific, unexpected, and nonroutine event or series of events that create high levels of uncertainty and threaten or are perceived to threaten an organization's high-priority goals" (Seeger, Sellnow, \& Ulmer, 1998, p. 233). Venette (2003) describes a crisis as "a process of transformation where the old system can no longer be maintained." The organizational crisis I will be analyzing is the health and safety of NFL players. This is an organizational crisis because health and safety 
concerns lead players to retire early or to never begin an NFL career in the first place. Some have even committed suicide due to the problems they were forced to endure, stemming from head trauma sustained during their careers (Hanzus, 2015; Goodbread, 2014; Bennet, 2011).

The purpose of this study is to examine what the NFL says about player health and safety, how it is being said, and why certain framing strategies are used at specific times. For example, when Junior Seau committed suicide in 2012, NFL statements focused on his time as a player and a pillar of the community rather than the underlying cause of why this could have happened (Darlington, 2012; La Canfora, 2012; Sessler, 2012). During the coverage of Seau's suicide, the idea that concussions could have played a role in his death entered the conversation. The NFL responded by writing an article mentioning to "[focus] on how much we don't know about Seau's death" (Rosenthal, 2012). Additionally, the NFL used an interview quote from Seau's ex-wife saying "Of course he had concussions... That didn't stop him... It's not ballet. It's part of the game" (Rosenthal, 2012). While this quote sounds like a negative because it is confirming that Seau experienced concussions, it is actually a positive. By saying "it's part of the game," it allows the reader to think that maybe every player has concussions and they aren't all committing suicide, therefore there must have been some other reason Seau chose to end his life in the fashion that he did. When the writer quoted someone with apparent authority of the situation, this allowed the NFL to plant the idea in the reader's head that this tragedy is not the fault of concussions, football, or the NFL.

I am bringing together two concepts to investigate this crisis. Framing and accounts have, to this point, been considered separate ideas. However, I maintain that 
they are intertwined and will show that connection with this research. I am attempting to integrate two approaches, frames and accounts, to demonstrate how the NFL utilizes organizational impression management. Being able to understand when and where these tactics are being used are important to research because this will contribute, not only to the organizational impression management sub-field, but the entirety of impression management and social psychology work.

\section{Chronic Traumatic Encephalopathy (CTE) and its impact on the NFL}

Chronic Traumatic Encephalopathy (CTE) is a fairly recent medical discovery. CTE is a degenerative brain disease typically seen in people who have had multiple concussions throughout their life, but this disease is most often specifically associated with professional football players (Fainaru-Wada \& Fainaru, 2013). It is derived from the research of Dementia pugilistica (DP), or "punch-drunk" disease that was attributed to years of boxing (Fainaru-Wada \& Fainaru, 2013). However, DP was thought to have only occurred in boxing, while CTE covers other sports and situations where there are repeated concussive and sub-concussive blows to the head (The New York Times, 2011).

While it was not the first article published in the journal Neurosurgery, Dr. Bennet Omalu's submission detailing the brain or former Pittsburgh Steelers center Mike Webster garnered the most controversy. Neurosurgery was the unofficial home for what are now called the "NFL Brain Papers" (Fainaru-Wada \& Fainaru, 2013). In 1994 then commissioner of the NFL, Paul Tagliabue, created a commission to study head injuries called the Mild Traumatic Brain Injury (MTBI) Committee. This committee was led by rheumatologist Dr. Elliot Pellman. This committee published fifteen papers in 
Neurosurgery all relating to concussions in professional football players. These papers made such claims as, "Professional football players do not sustain frequent repetitive blows to the brain on a regular basis" (Viano, et. al., 2005) and "...focal brain injury in the NFL seems to be exceedingly rare" (Pellman, et.al., 2004).

Since the initial conception of the MTBI Committee, multiple other independent research committees have been convened to study CTE specifically in NFL players. Some of these research centers include the Brain Injury Research Institute (BIRI) of which Dr. Omalu is a founding member and the CTE Center at Boston University, which is directly funded by the NFL. The research on CTE and its effects on NFL players culminated in 2007 when there was a United States Congressional Oversight meeting on the NFL retirement system (Schwarz, 2007). The NFL Players Association (NFLPA) alleged that the NFL does not adequately compensate its retired players concerning health care (Schwarz, 2007). In 2010, as a direct result from this hearing, the MTBI Committee was disbanded and rebranded as the NFL Head, Neck, and Spine Committee(Associated Press, 2010).). In 2013, the NFL reached a tentative $\$ 765$ million settlement with 18,000 retired players concerning concussion-related brain injuries (Associated Press, 2013). In 2014, this settlement was finalized to more than \$870 million (Associated Press, 2014).

The 2007 congressional hearing was a turning point in NFL concussion crisis. It took this issue out of whispered words behind the closed doors of locker rooms and thrust it into the national spotlight. A LexisNexis search found in 2006 there were 1,987 newspaper articles using the words "concussion" and "NFL;" In 2007, there were 2,312. The concussion crisis has permeated so much of the American consciousness that in 
2015 a feature film titled "Concussion" was released starring Will Smith, detailing the story of Dr. Bennet Omalu. In emails released in the 2015 Sony Pictures email hack, it was discovered that Sony deliberately altered or deleted parts of the film after pressure from NFL attorneys (Belson, 2015). By the NFL intervening on a film that they had declined to be a part of may be seen as an attempt to control the story, otherwise known as managing the impression of the NFL.

\section{The NFL in crisis}

With some background in CTE and its effect on the NFL, the question remains: Is the NFL truly in a crisis? Revisiting the definition of a crisis as "a process of transformation where the old system can no longer be maintained," (Venette, 2003) I will first explain what is considered the "old system" and how the concussion crisis did not allow for the system to continue to be maintained.

I consider the old system of professional American football to be pre-2007 congressional hearing. The separation is based on NFL rule changes. Since 1985, the league has implemented 66 rule changes relating specifically to player health and safety. Pre-2007, there was an average of 2.12 rule changes per year. Post-2007, that number rises to an average of 3.62 rule changes per year (NFL Football Operations, 2016).

Additional examples of crisis stem from public opinion. When public opinion moves rapidly towards the negative, an organization will do what they can to change that image. For example, during the initial stages of the 2015 FIFA investigation, many top FIFA officials, including the president at the time, were suspended from FIFA activities in an attempt to save face with the public. Public opinion of football is no 
different. In January 2015, Frontline conducted an online poll asking "How big of a problem do you think concussions in football are?" (Frontline, 2015). The results of that poll are below:

Figure 1.1

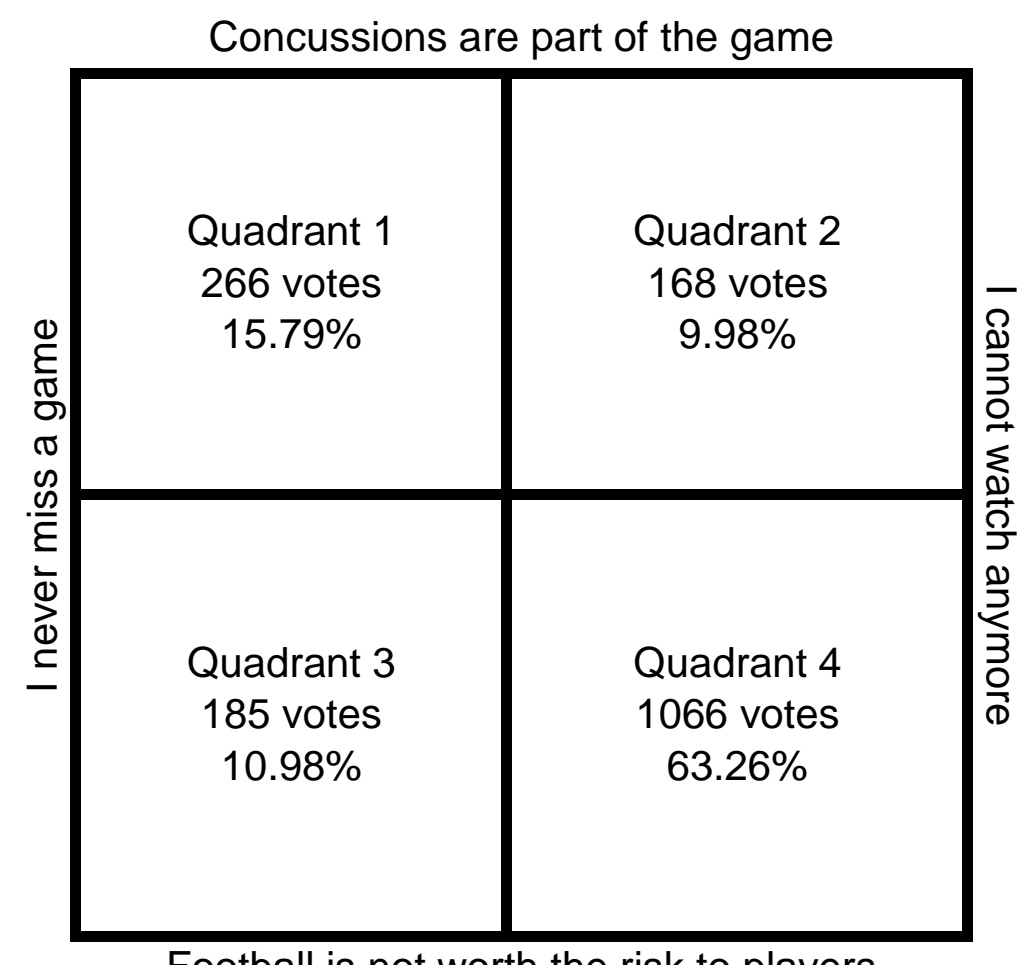

Football is not worth the risk to players

This poll was conducted on Frontline's website. To vote in the poll, participants chose one of the four quadrants to vote in which encompassed two statements. The numbers above are based on the comments section as it could be sorted by vote. However, a participant can vote without commenting, so the numbers above are likely lower than the actual number of all votes cast. Of the 1685 total votes, $63 \%$ of the votes were cast in quadrant 4 which says that "football is not worth the risk to players" and "I cannot watch anymore." Some of the comments from this quadrant exemplify the crisis the NFL is facing concerning concussions and the resulting public outcry. Two main 
arguments are shown through the comments section. The first being that people have stopped watching NFL games:

"I was born and raised a football fan, but after watching the show, and reading the research, I can't support this sport any more. I just can't enjoy watching people permanently injure themselves."

"I was a season ticket holder for years and went to one Superbowl. (NYG) I feel I cannot support this sport any longer. I do not attend or watch football any longer."

"One of many reasons I stopped wataching. [sic]"

"I no longer watch and hope parents will no longer encourage football."

If the NFL loses fans, it loses money. However, while many commenters have claimed they have stopped watching football, viewership is only rising for NFL games reaching a record number of 202 million unique viewers in 2014 (Baron, 2015). The unanswerable question is if that is because people are new fans or if the NFL's impression management strategies are bringing back prior fans, or both.

The second biggest claim in this section is the idea that many people will not let their children play football, youth or otherwise.

"I won't let my son play."

"I cannot in my right mind subject my kids to such an intentionally violent sport."

"My kids certainly won't be participating in it."

"[Concussions] have made sure that my son will not be playing [football] ever." 
The oft-cited statistic is that if $10 \%$ of mothers stop letting their children play football, that is the end of the NFL. Whether or not that is true, it is impossible to say. However, it is clear that the NFL has put forth many programs to increase safety awareness in youth football in an effort to encourage mothers to continue to let their sons play football. It is hard to say if this tactic is working. Many former NFL greats such as Brett Farve, Terry Bradshaw, and Troy Aikman have said they would not let their sons play football. This idea is shared by other influential people such as LeBron James and even President Obama (DeLessio, 2014). On the flip side, actor Will Smith, who portrayed Dr. Omalu in the 2015 film Concussion, has said that he would have to look at all the information before he would let his son play football again (NPR, 2015).

Additionally, Dr. Julian Balies, one of the original allies of Dr. Omalu and his fight against the NFL and arguably one of the most informed people about concussions and its effects, has said that he had let his sons play football and would have continued to let them do so if they had the desire (Healy, 2015).

This idea of the NFL being in crisis brings forth the idea of damaged versus spoiled identities. Goffman (1963) conceptualizes this idea from stigma and how these stigmas affect individual people. He defines stigma as, “...an attribute that is deeply discrediting," (p. 3). An organization can overcome a discrediting stigma, or persevere despite a stigma, however, if too many stigmas are collected it can shift an identity from damaged to spoiled. A damaged identity within organizations is when there is a perpetual blemish on the record of that company, but it still stands. For example, General Motors and its ignition switch recall in 2014 or Exxon and the Exxon-Valdez oil spill disaster in 1986. Both of these companies still stand today, despite the damage 
sustained during these times. However, if an organization has an identity that is so damaged that is becomes spoiled, then the organization cannot persist. For example, the Enron scandal in 2001 and Lehman Brothers involvement in the 2008 financial crisis. Both of these companies folded in the face of spoiled identities.

With all of this being said, is the NFL in crisis? I maintain that it is. While there are people on both sides of many of the issues, it comes down to the fact that if the NFL did not feel the issues of concussions were critical to the survival of the NFL, it would not be engaging in the various impression management strategies that it is. Additionally, I maintain that the NFL is operating with a stigmatized identity. It is not yet spoiled; however, it remains to be seen just how damaged its identity is.

\section{Conceptual Framework}

Impression management was made popular by Goffman (1959) in The Presentation of Self in Everyday Life. Goffman defined self-presentation in the context that an individual uses impression management to control and define each interaction he or she would have with someone else. Most studies of impression management examine interpersonal interactions (see Leary, 1995; Ellison, Heino, \& Gibbs, 2006). Impression management is also referred to as self-presentation, though some have distinguished between these two terms (see Schlenker, 1980; Schneider, 1981). However, the difference between these two terms is not trivial. Self-presentation is not always used in a strategic, tactical sense while impression management is a tactical approach. Often the reasoning for not distinguishing between these terms is dependent on the discipline in which the research is being conducted. Jones and Pittman (1982) created a taxonomy of "self-presentation strategies" to be used in differing situations. 
They created this because they thought that "impression management" wasn't specific enough. However, since then, other researchers have used Jones and Pittman to explain "impression management" and not self-presentation (see Connolly-Ahern \& Broadway, 2007). However, recently impression management research has branched out into other areas. My research focuses on when and how an organization crafts a public image through impression management.

The interest in organizational impression management rose to popularity through the 1970's and 1980's and peaked in the 1990's with the ubiquity of the Internet (Esrock \& Leichty, 1998; Clark, 2000). The area of organizational impression management is vast with a myriad of terms and definitions within the field (see Hutton, Goodman, Alexander \& Genest, 2001; Clark, 2000; Hooghiemstra, 2000; Gardner \& Martinko, 1988). Woods, Manning \& Matz (2015) define impression management as “...the strategic manipulation of social information." For the purposes of this research, organizational impression management refers to the strategic manipulation of social information by an organization.

There are many organizations that have experienced crisis (ex: General Motors, Bank of America, Enron, etc.). However, I have chosen to focus on sport institutions and specifically the National Football League. I chose sports not only for personal interest, but because I believe it is a somewhat neglected area of sociology. For a long time, sports sociology was described as being "scorned by sociologists [and] despised by sportspersons" (Bourdieu, 1988). Dave Zirin wrote a stirring article calling out sports sociologists by telling them to "get off the bench" (Zirin, 2008). Eckstein, Moss, and Delaney (2010) took up the mantle by analyzing sports sociology literature from 1977- 
2008 and determining where there are significant gaps in the literature. One of these gaps identified was sports and the media. Although studying media and sports was on the rise at the time of the Eckstien, et al. (2010) article, it is still a small field. Studying how sports organizations utilize organizational impression management is important because within the world of sports organizations there have been many image disruptions that require organizational impression management; Tour de France blood doping, NCAA football playoff selection, anti-Semitism during the 1936 Berlin Olympics, MLB steroid use, and the FIFA 2022 Qatar World Cup bribes, just to name a few.

A tactic commonly used within sport organizational impression management is framing (see Schmitt, 1991; Schwirin, Curry \& Woldoff, 2001; Benford, 2007; Smith \& Sanderson, 2015). Frames, as defined by Gitlin (1980 p. 6) involves "principles of selection, emphasis, and presentation composed of tacit little theories about what exists, what happens, and what matters." Essentially, frames are pieces of information that are presented in a specific way to ensure the public is led to believe which information is the most important. Gamson and Stuart (1992) states that frames are designed to suggest to the reader what the main issue is. The framer organizes information into meaningful categories, and in doing so, they create a message that implies some parts of the issue are more important than others (Entman, 1993; Miller \& Reichert, 2000). Scheff (2005) condenses all these ideas into a definition that says frames can be a single word, phrase, or proposition.

However, the biggest issue with the concept of framing is that it is an oft contested field of research. Many scholars cannot agree on a single definition of frames and framing and how it can be used. The first step is to clearly define the difference 
between "framing" (an action) and "frames" (a noun). Framing as an action is what people do. This is either what the producer of the content does to create a specific message, or, what the consumers of that content do when they see the frames created by the producer.

Entman (1993) calls this the "fractured paradigm," saying that frames and framing are "often defined casually, with much left to an assumed tacit understanding of the reader" (p.52). He goes on to explain that frames, and thus the action of framing, "select some aspects of a perceived reality and make them more salient in a communicating text, in such a way as to promote a particular problem definition, causal interpretation, moral evaluation, and/or treatment recommendation for the item described" (p. 52). This is saying that frames and framing really only exist in the reality of the producer and consumer.

Everything is framed one way or another. Scholars want to know why people have chosen to say or do certain things in a certain way. That's the backbone of sociology. Frames are being used in this research because how the NFL shapes its argument is important to know. It is interesting and crucial to understand how organizations talk about themselves, especially during a crisis of any kind.

Frames are useful because they help outline what the producer wants the audience to focus on. For example, political speech is rife with frames. One of the most popular frames in the current political landscape is the phrase "Obamacare" versus "Affordable Care Act." When the Affordable Care Act (ACA) was implemented, it was often shown that the Republican Party referred to it as "Obamacare" while the Democratic Party referred to it as the "Affordable Care Act." "Obamacare" was seen as 
a derogatory slur, inferring that everything that is wrong with Obama is everything that is wrong with Obamacare, while the Affordable Care Act was seen as a positive term, something associated with providing affordable healthcare (Aaker, 2013). This frame was hugely successful for both parties. In a poll conducted by Gallup, people were asked if they approved or disapproved of the ACA or Obamacare. When asked about the ACA, $45 \%$ approved and $49 \%$ disapproved. However, when asked about Obamacare, $38 \%$ approved while $54 \%$ disapproved (Grier, 2013). There is a distinguishing difference of the type of framing strategy used based on the intent of the producer. The intent of the producer is shaped by what kind of account they are attempting to make within their chosen frame.

To expand on the idea of "frames" versus "framing" from above, the word Obamacare is a frame. It is a specific word, idea, or phrase. However, when someone says "Obamacare" as opposed to ACA, he or she is framing the issue.

Similar to framing is the concept of accounts. Accounts is most famously described by Scott and Lyman (1968). Accounts are “...statements made to explain untoward behavior and bridge the gap between actions and expectations" (1968). Scott and Lyman broke down accounts into two general categories, excuses and justifications. Justifications are when the person accepts responsibility for the deviant action, but does not accept that the action is bad or wrong. Excuses are when the person accepts that the action is bad or wrong, but does not accept responsibility.

While accounts research has been applied to other research interests, the most comprehensive extension of accounts was written by Nichols (1990). Nichols creates a conceptual framework to better explain accounts and what is happening. Nichols says 
that Scott and Lyman only account for two scenarios where accounts would be needed, when in fact there are eight. Nichols first explains that there are remedial and preventative accounts.

Table 1.1

\begin{tabular}{|c|c|c|}
\hline \multicolumn{2}{|c|}{ Remedial and Preventative Accounts } \\
\hline Statement Formula & Remedial & Preventative \\
\hline $\begin{array}{c}\text { Admits wrongfulness, } \\
\text { admits responsibility }\end{array}$ & Admission & Disclaimer \\
\hline $\begin{array}{c}\text { Admits wrongfulness, } \\
\text { denies responsibility }\end{array}$ & Excuse & Pretext \\
\hline $\begin{array}{c}\text { Denies wrongfulness, } \\
\text { admits responsibility }\end{array}$ & Justification & Explanation \\
\hline $\begin{array}{c}\text { Denies wrongfulness, } \\
\text { denies responsibility }\end{array}$ & Denial & Neutralization \\
\hline
\end{tabular}

Remedial accounts refer to statements regarding "past behavior and emergent audience reactions" while preventative accounts refer to statements regarding "future behavior and anticipated audience reactions" (Nichols, 1990). This is an important distinction and extension of Scott and Lyman's work. Understanding if an account is remedial or preventative completely changes how it is used and responded to.

For example, the NFL often makes a point to talk about players taking responsibility for their own safety through the proper use of equipment or proper tackling procedures. This type of "player responsibility" frame is an excuse by the NFL. It is saying that the organization recognizes that there is a safety issue, however it does not accept that it is the fault of the organization, but instead the fault of the player. This would be classified as an excuse for Scott and Lyman's work. However, under the Nichols extension, it would be first classified as a remedial account as opposed to a 
preventative account, and then under remedial accounts, it would qualify as an excuse. Similarly, there is a frame often used by the NFL that I categorize as "Moms and Families" frame. This frame is used when talking about many of the youth sports organizations and camps that the NFL sponsors. Scott and Lyman's research does not account for this type of frame. However, the Nichols extension shows that this is a preventative account and an "explanation." This is when a person denies wrongfulness but accepts responsibility. The NFL is denying that there is anything wrong with the game of football, but is accepting responsibility to ensure that youth sports are safer.

Accounts are typically defined as a defensive impression management tactic (Gardner \& Avolio, 1998). Frames are also a type of impression management tactic. I propose that accounts are an extension of framing. Accounts are presented when responding to a crisis, however what is said in that response is framed in a very specific way. I will take the frames discovered within the NFL press releases and connect them back to accounts. The NFL is an organization that uses accounts just as many other organizations do. This research will extend both the accounts literature and the framing literature. How accounts are framed within an organizational crisis is a seemingly overlooked aspect of the literature.

The concepts of framing and accounts are helpful to the goal of studying organizational impression management because these are both impression management tactics. Expanding both research areas will strengthen the still small area of organizational impression management. Additionally, these two areas are the best for a tactical analysis of the NFL and its organizational impression management. 


\section{Methods}

This study uses an ethnographic content analysis to analyze the various frames used by the NFL when talking about player health and safety. An ethnographic content analysis is a "reflexive analysis of documents" (Altheide, 1987). Essentially, it is designed to find out not only what the document says on its face, but how it is being said. Altheide (1987) first defined this type of qualitative content analysis research. His research was designed to illustrate how a qualitative content analysis is useful for "discovering emergent pattern, emphasis and themes" (1987). Altheide applied this concept to television news broadcasts during the Iranian Hostage crisis. He called his data "topics," "themes," or "ideas." For my research, I am also delineating topics, themes, and ideas, but I am housing everything under the umbrella term of "frames."

I am using this method instead of a more traditional quantitative content analysis because my research will not be best served by giving a number of times the NFL says a word or phrase. The NFL is an extremely large and powerful company. Counting how many times it says something does not get to the heart of my research question. I want to know not only what the NFL is saying, but how. Qualitative research will best answer this question. Additionally, quantitative research is overwhelmingly more popular in the study of organizational impression management (see Gardner\& Martinko, 1988; Allen \& Calliouet, 1994; Hutton, et al., 2001; Massey, 2001; Chng, Rodgers, Shih \& Song, 2015; Woods, Manning \& Matz, 2015).

The data I am using comes from the NFL Communications website. This website is an archive of every press release the NFL has put out since January 2010 . On this website the articles can be divided by a number of categories. The category of articles I 
will be sampling from is "Player Health and Safety" $(N=209, n=41)$ starting from January 2010 to September 2014. I chose to use the pre-ordained category of "Player Health and Safety" instead of sampling from all available articles because this topic is exactly what I want to study. These articles were listed in chronological order. There are 209 units in my population, but I only read and analyzed every fifth article. With this sampling frame of five, I have a sample of 41 total units.

To obtain my results, I read each article and made notes of words or phrases that stood out. For example, since the category is already called "Player Health and Safety," I made a note each time an article used that phrase. This differs from a quantitative study because I am not interested in how many times the NFL used this term, but instead how it was used. For example, often times the NFL substituted the term "player health and safety" in place of the word "concussion" or "head trauma" when otherwise explicitly talking about that subject. Additionally, after reading all the articles I made notes about themes that I noticed over all. Then, with these themes in mind, I went back through the articles to find quotes to illustrate those themes.

\section{Grounded Theory}

My methodological approach is similar to Glaser and Strauss' grounded theory. Charmaz (2006) lays out the seven points that create a grounded theory approach to research;

1) Simultaneous involvement in data collection and analysis

2) Constructing analytic codes and categories from data, not from preconceive logically deduced hypotheses 
3) Using the constant comparative method, which involves making comparisons during each stage of the analysis

4) Advancing theory development during each step of data collection and analysis

5) Memo-writing to elaborate categories, specify their properties, define relationships between categories and identify gaps.

6) Sampling aimed toward theory construction, not for population representativeness.

7) Conducting the literature review after [sic] developing an independent analysis.

- Charmaz, 2006 p.4-5

Beginning with the first point, a simultaneous involvement in data collection and analysis means that as a researcher, the data is analyzed in real time as it is being collected. This applies to my research because as I read each press release, I made notes and analyzed the words, phrases, and sentences I saw. From that collection, I was able to draw a small amount of analysis that I carried to my next press release and so on until I had read all 41 press releases. This is also known as the constant comparative method, meaning that each time a new analysis is made, it is compared to the prior analyses.

Those small pieces of analysis are the codes and categories I was able to build from the data. I did not enter this project looking to answer a specific hypothesis that I had written out beforehand. Therefore, all data and analyses came organically instead of trying to answer a question. This also helped advance theory development. I did not 
enter this research knowing exactly how it would end. This advancement of theory development is how I came to add accounts to my original framing research plan.

The last three points of the grounded theory approach were not something I did as each are detailed here. This is why I said my approach was similar. I did not necessarily write "memos" in that traditional sense. I put all of my press releases and quotes into an organized spread sheet to be better able to see patterns and connections. This is how I was able to specify properties and define relationships between different frames and accounting techniques.

My sampling was not done towards theory construction, but instead for population representatives. I did this because I wanted to be able to apply the frames I found through this research to other aspects of the NFL and its communications. Finally, I wrote my conceptual framework first because I was unsure of how to best go about this type of research. Although, the conceptual framework has changed significantly from the beginning to post-data collection.

I conducted my work in the spirit of grounded theory, but I did not follow it to the letter. I chose to deviate slightly from the grounded theory ideals because I found that my research was best served with said deviations.

\section{Results}

\section{a. "Player Health and Safety"}

The first frame is when the NFL uses the term "player health and safety." This is a frame because it is typically used as a placeholder for concussions. The League often tries to subvert the use of the word "concussions" by diluting its impact by saying "player health and safety" instead. The first place I found this frame was on the press release 
website under its selection of categories. In fact, as stated in methods, the population of press releases came from the category of "Player Health and Safety." Another time the term "Player Health and Safety" is seen in a pronounced fashion is when the NFL published its "NFL Health and Safety Update." This one-to-two-page document started November 16, 2012 and was released once a week during the time frame I am studying.

In a December 16, 2012 release titled, "NFL's Merton Hanks: 'Health and safety of an individual player is more important than any game"' Hanks says, "Concussions are an issue in all sports. We want to make sure that every athlete understands concussions," but then qualifies in the next sentence by saying "In today's NFL, we have made the point that we are going to make player safety a priority." Even though Hanks clearly is talking about concussions, he reverts back to the frame of "player safety" as to indicate that he might be referring to something other than concussions. "Player health and safety" is also used to talk about the NFL's commitment to keeping players safe. In a NFL Health and Safety Update dated October 30, 2013, the League conducted a Q\&A with NFL Physicians Society President Dr. Matthew Matava. A question is posed asking, "When people ask you about the conflicts between working for a team and making players' best interests a priority, what do you tell them?" Dr. Matava answers,

"I tell them that our first, second, and third priorities as NFL physicians are player health and safety. What is best for the player is typically best for the team anyway. The stakes are too high and the implications too significant 
to let competitive issues influence our medical judgment. Fortunately, coaches, general managers, and team owners realize the importance of player safety, as well as the fact that rushing a player back in prematurely usually results in an even longer period of recuperation from the original injury"

This indicates that playing through an injury, any injury, is bad for players and bad for the team. Again using the term "player health and safety" as an attempt to encompass every possible safety issue in football. However, later in the session when asked about medical resources available on the sideline, Dr. Matava makes a point to say this;

"In addition, there is an independent neuro-trauma specialist (typically a neurosurgeon) present on each sideline to assist with the diagnosis of concussions."

While this is an important addition to the medical staff, to have to point it out so specifically indicates that "player health and safety" is referring to concussions. While he does add that sidelines contain "25-27 medical personnel immediately available for any injury scenario," to have to highlight and only highlight one of the 25 is odd if player health and safety is really about all health issues facing players.

This frame is a neutralization account. A neutralization is when the actor denies wrongfulness and responsibility in a preventative context. The frame of "player health and safety" is first a preventative account because the NFL is trying to subvert the use of the word "concussion" but supplementing with the term "player health and safety." This neutralization is attempting to deemphasize the idea of concussions or dilute the 
conversation about concussions. The NFL is attempting to have the framing effect of "player health and safety" connected with other less serious issues, like a broken finger, rather than extremely serious conditions such as head trauma. It denies wrongfulness because it is talking about the health and safety of a player, a positive, as opposed to the injury and danger of a player, a negative.

\section{b. Player responsibility}

Another frame is the idea that players would be safer if they took responsibility for themselves. The NFL is implicitly and explicating placing blame on the players for getting hurt. For example, in a release on July 20, 2010, it is said that "Many NFL players have abandoned knee, thigh and hip pads to try to gain a speed edge...Many wide receivers, defensive backs and linebackers wear little more than helmets and shoulder pads. But Commissioner Roger Goodell wants to make the game safer for players ... The league also wants to set a safety example for college and high school players." This quote is first explicating saying that players are disregarding their safety equipment, thus implying that if these players then get hurt it is their own fault. It then goes on to say that "Commissioner Goodell wants to make the game safer..." implying that the NFL wants these players to be doing the right thing, but that the League can't be held responsible if they choose not to.

The other main issue that the NFL says players need to take responsibility for is playing by the rules. By this, they mean that players need to tackle correctly, follow the rules on the field, not use illegal techniques and so on. A release on October 19, 2010 goes into this idea in detail. NFL executive vice president Ray Anderson was on the ESPN Radio program Mike \& Mike Show discussing "the need for more stringent 
enforcement of the current rules against illegal hits to the head." He goes on to say that the NFL is going to "enforce the existing rules much more to the letter of the law so that we can protect our players." He is implying that players that don't follow the rules get hurt. He even goes so far as to invoke the legal parameters of his argument, saying that being held accountable for breaking the rules is "strict liability."

This idea of equipment being worn correctly or at all, along with following proper rules and techniques is an idea that is reiterated multiple times. For example, there was a release dated December 9, 2010 where its entire purpose was to tell players to take responsibility for their play and their actions. In fact, it was titled, "Univ. of North Carolina doctor on minimizing concussions: "We need to focus on teaching how to tackle appropriately."' Within this article, said University of North Carolina doctor, Dr. Kevin Guskiewicz, said, "We stand a much better chance of minimizing concussions and eventually preventing concussions by behavior modification." This statement means that if players would just follow the rules and play differently, concussions would be less of a problem, and eventually not an issue at all.

In a release dated November 20, 2012, the Player Safety Advisory Panel released a video to players explaining that they can play aggressive and physical football while still following the rules, as evidences by that seasons' AFC Championship, NFC Championship, and Super Bowl XLVI games. In a memo given to the players written by the co-chairman of the committee, Hall of Famer Ronnie Lott, he said, "Our panel believes that this demonstrates that it is possible to play championship football while observing the rules of the game and not engaging in acts that sometimes leas to altercations, penalties, and fines - or worse, injuries." This is implying that players that 
don't follow the rules are taking unnecessary risks that are causing problems injuries. Additionally, explicitly stating that if championship teams can play clean, so can you.

This type of frame is a remedial account called an excuse. An excuse is when the actor admits the wrongfulness of the behavior, but denies responsibility. One of the main techniques of making an excuse is scapegoating. This is something the NFL is definitely doing when talking about player responsibility. They are admitting that players are getting hurt, but then using those players as a scapegoat. Saying that these players wouldn't have these injuries or issues if they would wear the proper equipment and follow the rules. Additionally, the league claiming that it can't be held responsible if its players don't wear proper equipment is bizarre. If the league thinks this is such a problem, it can enforce the rules to say that players cannot enter a contest without proper equipment. However, the league allows players to compete without proper equipment and then places the onus on the player to take responsibility for his own safety.

\section{c. Moms and Families}

One of the biggest issues with the concussions in the NFL is the idea that once mothers stop letting their children play football, that is the end of the sport. The NFL is obviously in the business of football and doesn't want that to happen. Thus, often the NFL references or talks about how they are keeping youth football players (and youth athletes of all sports) safe. For example,

"We can help athletes of all ages stay active and healthy by knowing the facts about concussions and when it is safe for athletes to return to play."

- August 22, 2010 
“...make the game safe for youngsters..." - November 11, 2010

"...focusing on educating players and their families, coaches and others

on preventative safety measures for young athletes." - April 10, 2012

“...put the safety of our kids first." - February 27, 2013

"This is a perfect example of our shared commitment to making the culture of sports better and safer - especially for young athletes." - September 4, 2013

The other aspect of the family frame is when the NFL specifically addresses "moms." This is evident when the NFL holds events like the "Youth Football Clinic for Moms and Kids" (May 22, 2013) or the "OSU-NFL Moms Football Safety Clinic" (July 3, 2013). These events are designed to speak directly, and only, to the mothers of young boys playing football. In a press release from July 24, 2014 there was a specific "Mom's Clinic" held at the Arizona Cardinal's stadium which was designed to "showcase the family connections to [Heads Up Football]." However, when talking about families the NFL either says "parents" or "moms" but does not ever address fathers.

This frame is a preventative account called a disclaimer. A disclaimer is when the actor admits the wrongfulness of the behavior and admits responsibility for the action. However, the disclaimer is preventative because the actor is using a disclaimer to say they did something wrong, but to wait and see how they will fix it to prevent this type of action in the future.

The NFL takes responsibility for keeping youth athletes safe and also admits to the fact that youth athletes also experience concussions. They are asking for a suspension of judgement until they can properly inform parents about their efforts to 
rectify any youth sport safety situations. This suspension of judgement extends into the idea of positive publicity. The league is attempting to craft an image that says that they are not just committed to football safety, but youth safety in all sports.

\section{d. Not Just a Football Problem}

Something the NFL calls attention to often is that concussions are not just an issue within professional American football. This is tied back to the idea of children in

youth football, however many people, including the NFL, refer to them as the "standard bearer" in this issue (October 19, 2010). Often times, when the NFL is talking about keeping football players safe, they say instead "athletes" as to indicate that this is a problem outside of professional football. For example,

"...take this opportunity to talk with your coaches, parents, athletes, and others about concussions in all sports..." - August 22, 2010 "We will share our medical expertise broadly to benefit athletes in every single sport."- October 27, 2010

"Concussions are an issue in all sports." - December 16, 2010

In addition to expanding the issue of concussions to encompass all athletes playing any sport anywhere, the NFL often tries to make it seem as if their research will benefit the lay person as well. A 2013 press release titled "Foundation for the NIH Joins NIH in Seeking Proposals to Study Sorts-Related Brain Injuries" exemplifies this exact point. The first mention of "non-athletes" comes from Maria Freire, President of the Foundation for NIH She says, "Thanks to the generosity of the NFL, the program will provide us with invaluable data and ultimately ways to prevent and treat injuries in ways that will benefit athletes and non-athletes alike." She is seen as someone with authority 
of the situation because she is the president of this medical group. She is saying that the average person who had experienced a concussion would be worse off if it were not for the NFL and their research. This statement is qualified by Commissioner Goodell saying, "The research and results generated by the SHRP will help medical professionals understand more about head injuries not only in athletes, but also in the general population."

Again, using someone in a position of authority to show that the NFL is helping, not only its players, but the average Joe who falls down and knocks his head. This type of frame is a preventative account, however, it can fall into two different account categories; either a disclaimer or a pretext. It can be a disclaimer because the NFL is admitting that concussions are an issue and taking responsibility to make all athletes safe, including the ones that play in the NFL. During a preventative disclaimer the actor appeals to the audience to suspend judgement, asking them to allow them to show what they are going to do before worrying about what could happen. This is more in line with what the NFL is doing with this frame because they are asking the public to trust them and that they will help all athletes everywhere, and even non-athletes.

However, this frame can also be seen as a preventative account called pretext. A pretext account has the actor accept wrongfulness of the act, but denies responsibility. By the NFL saying concussions are an issue in "all sports" it is denying responsibility by saying concussions exist in the nature of sports. Therefore, even though concussions have been a problem in football, it isn't the League's responsibility to take blame for every head injury across all sports. Prior research, medical and otherwise, indicates evidence that there is something specific to football that increases the prevalence of 
head trauma, concussions, and eventually CTE, even if concussions are a part of other sports. The NFL is trying to create a frame that leads the reader away from that conclusion.

This frame is one of two times the NFL engages in identity linking. Identity linking is when one identity is promoted or discredited through its attachment to another identity. For example, in the 2016 presidential race, Republican candidate Donald Trump is seen by some as a racist because of an endorsement from the Ku Klux Klan; Thus linking the identity of Donald Trump to the heinous KKK organization (Bradner, 2016).

In the case of the frame of "Not Just a Football Problem," the NFL is linking its identity with all other sports. By this, I mean that the NFL is attempting to show that since other sports have the issue too, that concussions are a "sports" issue and not a "football" issue. This is an attempt to spread the blame or dilute the stigma associated with the NFL concerning concussions.

e. The Military and the NFL

An extension of the "not just a football problem" frame is that concussions are also a problem in the military and therefore NFL's research is going to benefit soldiers. The NFL makes a point to connect the military to football. The idea behind this is to show that the NFL supports out troops, not just financially or socially, but medically helping our soldiers deal with the trauma from concussions sustained in active combat.

In a December 9, 2010 press release, the NFL held and player health and safety conference to talk about helmet technology and its impact on reducing on concussions. Doctors from the NFL's head, neck and spine committee were present along with 
"helmet manufacturers, researchers, the military and NASCAR." The rest of the article talks about how the NFL has a responsibility to play a safer game, but the military was still invited to benefit from the research. Following this, on September 12, 2012 Commissioner Goodell and the Army Vice Chief of Staff launch an NFL-Army joint initiative to research head injuries.

Additionally, in an NFL Health and Safety Update released on March 13, 2012 General Electric (GE) and the NFL announced a "Head Health Initiative" which has a goal to "improve the safety of athletes, members of the military and society overall." This is another time where the NFL is implying that concussions matter beyond professional American football and, moreover, that the NFL is doing a service in helping these other groups of people. Specifically, the NFL is again linking how football players and soldiers, implying they are on the same plane.

Finally, in an NFL Health and Safety Update released on May 22, 2013, there was a "Concussion Culture Change Forum" hosted by the NFL at Fort Bragg. It was a partnership between the Carolina Panthers and the United Service Organizations (USO) of North Carolina. This forum engaged players and about 100 military service members from the Army, Air Force, Department of Defense civilians and their families in a discussion about the culture in the military and in the NFL about injury and reporting said injuries. This press release married the ideas of football and the military within one sentence; "The group discussed football's and the military's cultural responses to injury, focusing on enhanced concussion awareness and diagnosis, return to play and return to action protocols and other health related topics." 
By never addressing football or the military alone, the NFL is attempting to frame that they are one in the same; the NFL and US Military. What the NFL does within the field of research is being done to benefit, not just players, but our brave men and women serving is active combat situations all over the world. This frame is a remedial account called an admission. This is an admission because the NFL is accepting that concussions exist and taking responsibility to research it. The specific thing that makes this an admission is that the NFL is offering assistance to other people. The NFL is showing that they have this issue and they are doing what they can to remedy it, but additionally that they can help solders in combat who also experience brain trauma.

While these press releases don't give an explicit reason as to why the NFL wants to align itself with the military and veterans, some conclusions can still be drawn. For example, veterans are often seen in a positive light. The NFL could be trying to garner some of that positive spotlight for its players and its game. Additionally, veteran that experience injury or trauma are often hailed as heroes and given sympathy. The NFL could be trying to have this same idea apply to players. Many people have said that they do not feel bad for players with brain damage because they are just "overpaid athletes" (Frontline, 2015). The NFL could be trying to get people to see that these players are putting themselves on the line for the American people, just as solders do every day.

This is the second time the NFL engages in identity linking. The NFL is linking its somewhat damaged identity with the pristine identity of the US Military. This is analogous to the idea of providing a reference for someone when he or she is trying to get a job. By linking a positive identity to another person, it increases the positive scale 
of that person identity. This is what is being done with the NFL and the military. By linking the pristine US Military identity to the damaged NFL identity, it creates the idea in people's minds that maybe the NFL isn't so bad after all if the military supports it. Thus repairing the NFL's identity, though to what extent cannot yet be measured.

\section{Conclusion}

The frames detailed here are just some of the major themes I could identify. These frames show what the NFL is talking about in relation to concussions. These frames shape how the NFL presents itself. For example, connecting the military and the NFL comes up again when the players wear military inspired camo uniforms during games over Veteran's Day weekend. These frames can obfuscate the real issue of concussions behind helping soldiers and comforting the minds of moms whose sons play football. The effectiveness of these frames would be the next step in this research.

One of the major limitations of this research is the replicability. The NFL Communications website was changed in October 2015. The site is no longer organized in the same categories that it was previously. Additionally, the website only houses articles for the current season. To access additional content, you must prove you are a sports journalist and provide the NFL with your credentials and only then will they issue access. I was unable to gain access to additional areas of the site so I cannot speak to what else the site may or may not have.

However, despite the limitations of this research there is benefit for future researchers. This same research idea can be applied to other sports organizations, and most organizations in general. Additionally, by taking the frames I have delineated here one could create a quantitative content analysis project and look for these frames in 
other places within the NFL or other news outlets. The greatest benefit of this research is the door that has now been opened to the integration of frames and accounts. By connecting these two conceptual approaches, future researchers can build on this idea and push both fields of framing and accounts forward in sociological research.

In the grand scheme of things, what does this all mean? Well, players are now coming forward to say that they regret playing football and that the health issues of concussions were never clearly explained (Knowlton, 2016). Also, college players are choosing to not go into the NFL Draft and play professional football because of fear of concussions (Trotter, 2014). But perhaps, most importantly, reported concussions during the 2015 season rose $58 \%$ over the 2014 season (Vinton, 2016). Does this mean the League's message is working and players are being more cognizant of the danger of concussions? Or does this mean that the game isn't "as safe as it's ever been" like Commissioner Goodell keeps saying? Also, what does this research say about the NFL current identity? On a scale between pristine and spoiled, I maintain that its identity lies somewhere in the middle. The NFL is not completely dismantled as it is still an active and profitable company, similar to General Motors and dissimilar to Enron. However, the NFL would not have employed the strategies shown in this research if its identity was not damaged in some way. Is the NFL winning the framing contest against those who are actively fighting against it? The NFL is sometimes colloquially referred to as the "No Fun League;" did this crisis encourage that idea? Unfortunately, this research cannot answer these above questions, or a myriad of others, but it can provide a stepping stone to understanding the consequences of organizational impression management within the NFL and beyond. 


\section{References}

Aaker, D. (2013). Obamacare: Is the Republican Framing Win in Jeopardy? Retrieved October 1, 2015, from www.prophet.com:

https://www.prophet.com/blog/aakeronbrands/160-obamacare-is-the-republicanframing-win-in-jeopardy

Allen, M. W., \& Caillouet, R. H. (1994). Legitimation Endeavours: Impression Management Strategies Used by an Organization in Crisis. Communication Monographs, 61(1), 44-62.

Altheide, D. (1987). Ethnographic Content Analysis. The Sage Enclyclopedia of Qualitative Research Methods, 10(1), 65-77.

Associated Press. (2010). NFL picks new co-chairs of updated concussion committee. Retrieved August 27, 2015, from www.NFL.com: http://www.nfl.com/news/story/09000d5d816fb87d/article/nfl-picks-new-cochairsof-updated-concussion-committee

Associated Press. (2013). NFL, ex-players agree to $\$ 765 \mathrm{M}$ settlement in concussions suit. Retrieved August 27, 2015, from www.NFL.com: http://www.nfl.com/news/story/0ap1000000235494/article/nfl-explayers-agree-to765m-settlement-in-concussions-suit

Associated Press. (2014). Federal judge approves NFL concussion settlement. Retrieved August 27, 2015, from www.NFL.com: http://www.nfl.com/news/story/0ap2000000363672/article/federal-judgeapproves-nfl-concussion-settlement

Baron, S. (2015). NFL 2014 TV Recap: 202 Million Viewers, Game Viewership Nearly Triples Broadcast Primetime. Retrieved April 1, 2016, from www.tvbythenumbers.zap2it.com: http://tvbythenumbers.zap2it.com/2015/01/09/nfl-2014-tv-recap-202-millionviewers-game-viewership-nearly-triples-broadcast-primetime/

Belson, K. (2015). Sony altered 'Concussion' film to prevent N.F.L. protests, emails say. Retrieved October 22, 2015, from www.NewYorkTimes.com: http://www.nytimes.com/2015/09/02/sports/football/makers-of-sonys-concussionfilm-tried-to-avoid-angering-nfl-emails-show.html

Benford, R. (2007). The College Sports Reform Movement: Reframing the "Edutainment" Industry. The Sociological Quarterly, 48(1), 1-28.

Bennett, D. (2011). www.businessinsider.com. Retrieved August 27, 2015, from Dave Duerson's Suicide Note: "Please, See That My Brain Is Given To The NFL's Brain Bank": http://www.businessinsider.com/dave-duersons-suicide-note-2011-2 Bourdieu, P. (1988). Program for a Sociology of Sport. Sociology of Sport Journal, 5(1), 153-161.

Bradner, E. (2016). Donald Trump stumbles on David Duke, KKK. Retrieved April 16, 2016, from www.cnn.com: http://www.cnn.com/2016/02/28/politics/donald-trumpwhite-supremacists/ 
Charmaz, K. (2006). Constructing Grounded Theory: A Practical Guide through Qualitative Analysis. London, England: SAGE Publications.

Chng, D. H., Rodgers, M. S., Shih, E., \& Song, X.-B. (2015). Leaders' impression management during organizational decline: The roles of publicity, image concerns, and incentive compensation. The Leadership Quarterly, 26(1), 270285.

Clark, C. E. (2000). Differences Between Public Relations and Corporate Social Responsibility: An Analysis. Public Relations Review, 26(3), 363-380.

Connolly-Ahern, C., \& Broadway, S. C. (2007). The importance of appearing competent: An analysis of corporate impression management strategies on the World Wide Web. Public Relations Review, 33(1), 343-345.

Darlington, J. (2012). Junior Seau remembered for fun, energy he brought to football. Retrieved October 21, 2015, from www.NFL.com: http://www.nfl.com/news/story/09000d5d828d2a94/article/junior-seauremembered-for-fun-energy-he-brought-to-football

DeLessio, J. (2014). 9 NFL Players Who Wouldn't Let Their Sons Play Football. Retrieved April 1, 2016, from www.nymag.com: http://nymag.com/daily/intelligencer/2014/11/9-nflers-who-wont-let-their-sonsplay-football.html

Eckstein, R., Moss, D. M., \& Delaney, K. J. (2010). Sports Sociology's Still Untapped Potential. Sociological Forum, 25(3), 500-518.

Ellison, N., Heino, R., \& Gibbs, J. (2006). Managing Impressions Online: SelfPresentation Processes in the Online Dating Enviorment. Journal of ComputerMediated Communication, 11(1), 415-441.

Entman, R. (1993). Framing: Toward Clarification of a Fractured Paradigm. Journal of Communication, 43(4), 51-58.

Esrock, S. L., \& Leichty, G. B. (1998). Social Responsibility and Corporate Web Pages: Self-Presentation or Agenda Setting? Public Relations Review, 24(3), 305-319.

Fainaru-Wada, M., \& Fainaru, S. (2013). League of Denial: The NFL, Concussions, and the Battle for Truth. New York City, New York: Crown Archetype.

Frontline. (2015). How Big of a Problem Do You Think Concussions Are in Football? Retrieved April 1, 2016, from www.Frontline.com: 2016

Fucillo, D. (2014). 49ers sign Jimmie Ward, Chris Borland to rookie contracts. Retrieved September 7, 2015, from www.ninersnation.com: http://www.ninersnation.com/2014/5/22/5743302/49ers-sign-jimmie-ward-chrisborland-rookie-contracts-salary-cap

Gamson, W. A., \& Stuart, D. (1992). Media Discourse as a Symbolic Contest: The Bomb in Policial Cartoons. Sociological Forum, 7(1), 55-86.

Gardner, W. L., \& Avolio, B. J. (1998). The Charismatic Relationship: A Dramaturgical Perspective. The Academy of Management Review, 23(1), 32-58.

Gardner, W. L., \& Martinko, M. J. (1988). Impression Management in Organizations. Journal of Management, 14(2), 321-338. 
Gitlin, T. (1980). The Whole World is Watching: Mass Media in the Making and Unmaking of the New Left. Berkeley, CA: University of California Press.

Goffman, E. (1959). The Presentation of Self in Everyday Life. Garden City, New York: Doubleday.

Goffman, E. (1963). Stigma: Notes on the Management of Spoiled Identity. New York, New York: Simon \& Schuster, Inc.

Goodbread, C. (2014). West Virginia QB Clint Trickett retiring due to concussions. Retrieved August 27, 2015, from www.NFL.com:

http://www.nfl.com/news/story/0ap3000000449424/article/west-virginia-qb-clinttrickett-retiring-due-to-concussions

Grier, P. (2013). 'Obamacare' vs. 'Affordable Care Act': Does the name matter? Retrieved October 2, 2015, from www.csmonitor.com: http://www.csmonitor.com/USA/Politics/Decoder/2013/1129/Obamacare-vs.Affordable-Care-Act-Does-the-name-matter

Hanzus, D. (2015). San Francisco 49ers' Chris Borland retiring from NFL. Retrieved September 7, 2015, from www.NFL.com: http://www.nfl.com/news/story/0ap3000000479460/article/san-francisco-49erschris-borland-retiring-from-nfl

Healy, M. (2015). Doctor featured in 'Concussion' explains why he let his sons play football. Retrieved April 1, 2016, from www.latimes.com: http://www.latimes.com/science/sciencenow/la-sci-sn-concussion-movie-julianbailes-20151223-htmlstory.html

Hooghiemstra, R. (2000). Corporate Communication and Impression Management New Perspectives Why Companies Engage in Corporate Social Reporting. Journal of Business Ethics, 27(1), 55-68.

Hutton, J. G., Goodman, M. B., Alexander, J. B., \& Genest, C. M. (2001). Reputation management: the new face of corporate public relations? Public Relations Review, 27(3), 247-261.

Jones, E. E., \& Pittman, S. T. (1982). Toward a General Theory of Strategic SelfPresentation. In J. Suls (Ed.), Psycological Perspectives on the Self (Vol. 1, pp. 231-262). Hillsdale, New Jersey: Lawrence Erlbaum Associates.

Knowlton, E. (2016). Former NFL player regrets playing football, says he's losing his memory and can't go down the stairs. Retrieved April 1, 2016, from www.businessinsider.com: http://www.businessinsider.com/former-nfl-playerantwaan-randle-el-regrets-playing-football-2016-1

La Canfora, J. (2012). Junior Seau: San Diego's can't-miss kid who never did. Retrieved October 21, 2015, from www.NFL.com: http://www.nfl.com/news/story/09000d5d828d6ac7/article/junior-seau-sandiegos-cantmiss-kid-who-never-did

Leary, M. R., \& Kowalski, R. M. (1990). Impression Management: A Literature Review and Two Component Model. Psychological Bulletin, 107(1), 34047. 
Massey, J. E. (2001). Managing Organizational Legitimacy: Communication Strategies for Organizations in Crisis. Journal of business Communiation, 38(2), 153-182.

Miller, M. M., \& Riechert, B. P. (1999). Interest group strategies and jornalistic norms: News media framing of enviormental issues. In S. Allen (Ed.), Enviromental Risks and the Media (pp. 45-55). London, England: Routledge.

NFL Football Operations. (2016). 30 Years of Health and Safety Rule Changes. Retrieved March 15, 2016, from www.operations.nfl.com: http://operations.nfl.com/football-ops/league-governance/health-safety/30-yearsof-health-safety-rule-changes/

Nichols, L. (1990). Reconceptualizing Social Accounts: An Agenda for Theory Building and Empirical Research. Current Perspectives in Social Theory, 10(1), 113-144.

NPR. (2015). Actor (And Football Dad) Will Smith On Playing The 'Concussion' Doctor. Retrieved April 1, 2016, from www.npr.com: http://www.npr.org/2015/12/23/460717256/actor-and-football-dad-will-smith-onplaying-the-concussion-doctor

Ozanian, M. (2014). The NFL's Most Valuable Teams. Retrieved September 7, 2015, from www.forbes.com: http://www.forbes.com/sites/mikeozanian/2014/08/20/thenfls-most-valuable-teams/\#2c3c1de579e9

Paulsen. (2013). 2013 Ratings Wrap: NFL Dominates List of Most-Watched Sporting Events. Retrieved September 7, 2015, from www.sportsmediawatch.com: http://www.sportsmediawatch.com/2013/12/2013-ratings-wrap-nfl-dominates-listof-most-watched-sporting-events/

Pellman, E. J., Viano, D. C., Casson, I. R., Tucker, A. M., Waeckerle, J. F., Powell, J. W., \& Feuer, H. (2004). Concussion in Professional Football: Repeat Injuries Part 4. Neurosurgery, 55(4), 860-876.

Price, T. (2014). San Francisco 49ers Draft LB Chris Borland. Retrieved September 7, 2015, from www.49ers.com: http://www.49ers.com/news/article-2/San-Francisco49ers-Draft-LB-Chris-Borland/bc2c2af2-08a4-4265-9e5a-08a07889cab8

Rosenthal, G. (2012). Seau's ex-wife talks of concussions as autopsy results near. Retrieved October 21, 2015, from www.NFL.com: http://www.nfl.com/news/story/09000d5d828d9b69/article/seaus-exwife-talks-ofconcussions-as-autopsy-results-near

Scheff, T. J. (2005). The Structure of Context: Deciphering "Frame Analysis". Sociological Theory, 23(4), 368-385.

Schmitt, R. L. (1991). Strikes, Frames, And Touchdowns: The Institutional Struggle For Meaning In The 1987 National Football League Season. Symbolic Interaction, 14(3), 237-259.

Schwarz, A. (2007). Congress Scolds N.F.L. and Union. Retrieved April 16, 2016, from www.nytimes.com: http://www.nytimes.com/2007/06/27/sports/football/27nfl.html

Schwirian, K. P., Curry, T. J., \& Woldoff, R. A. (2001). Community Conflict Over Area and Stadium Funding: Competitive Framing, Social Action, and the Socio-Spacial Perspective. Sociological Focus, 34(1), 1-20. 
Scott, M. B., \& Lyman, S. M. (1968). Accounts. American Sociological Review, 33(1), 46-62.

Seeger, M. W., Sellnow, T. L., \& Ulmer, R. R. (1998). Communication, Organization, and Crisis. Communication Yearbook, 21(1), 231-275.

Sessler, M. (2012). Jim Harbaugh: Junior Seau was world-class teammate. Retrieved October 24, 2015, from www.NFL.com:

http://www.nfl.com/news/story/09000d5d828d69b1/article/jim-harbaugh-juniorseau-was-worldclass-teammate

Smith, L. R., \& Sanderson, J. (2015). I'm Going to Instagram It! An Analysis of Athlete Self-Presentation on Instagram. Journal of Broadcasting \& Electronic Media, 59(2), 342-358.

The New York Times. (2011). www.slapshot.blogs.nytimes.com. Retrieved August 27, 2015, from Boston University Doctor Answers Questions from Readers:

http://slapshot.blogs.nytimes.com/2011/12/06/boston-university-doctor-answersquestions-from-readers/

Trotter, J. (2014). Clint Trickett to Quit Football. Retrieved October 30, 2015, from www.espn.com: http://espn.go.com/collegefootball/bowls14/story/_/id/12081388/clint-trickett-west-virginia-mountaineersstop-playing-football-concussions

Venette, S. (2003). Risk communication in a High Reliability Organization: APHIS PPQ's inclusion. Ann Arbor, MI: UMI Proquest Information and Learning.

Viano, D. C., Casson, I. R., Pellman, E. J., Bir, C., Zhang, L., Sherman, D. C., \& Boitano, M. A. (2005). Concussion in Professional Football: Comparison with Boxing Head Impacts-Part 10. Neurosurgery, 57(6), 1154-1172.

Vinton, N. (2016). Concussions are on the rise in the NFL: League releases data that shows 58\% increase in regular season concussions. Retrieved April 1, 2016, from www.nydailynews.com:

http://www.nydailynews.com/sports/football/concussions-rise-nfl-league-datareveals-article-1.2513828

Woods, J., Manning, J., \& Matz, J. (2015). The Impression Management Tactics of an Immigration Think Tank. Sociological Focus, 48(4), 355-372.

Zirin, D. (2008, July 1). Calling Sports Sociology Off the Bench. Contexts, pp. 28-31. 


\section{Appendix A: Data Sources - Chronological}

NFL Staff. (2010, April 20). NFL donates \$1 million to Boston University to study brain injuries. Retrieved September 1, 2015, from nflcommunications.com:

http://www.nflcommunications.com/2010/04/20/nfl-donates-1-million-to-bostonuniversity-to-study-brain-injuries/

NFL Staff. (2010, July 13). John Harbaugh named to NFL committee looking at player safety and other ways to improve game. Retrieved September 1, 2015, from nflcommunications.com: http://www.nflcommunications.com/2010/07/13/johnharbaugh-named-to-nfl-committee-looking-at-player-saftey-and-other-ways-toimprove-game/

NFL Staff. (2010, July 20). Commissioner Goodell wants to make game safer for players. Retrieved September 1, 2015, from nflcommunications.com:

http://www.nflcommunications.com/2010/07/20/commissioner-goodell-wants-tomake-game-safer-for-players/

NFL Staff. (2010, August 22). CDC works with NFL on concussion awareness. Retrieved September 1, 2015, from nflcommunications.com: http://www.nflcommunications.com/2010/08/22/cdc-works-with-nfl-onconcussion-awareness/

NFL Staff. (2010, September 27). Youth player safety and concussion awareness campaigns underway. Retrieved September 1, 2015, from nflcommunications.com: http://www.nflcommunications.com/2010/09/27/youthplayer-safety-and-concussion-awareness-campaigns-underway/

NFL Staff. (2010, October 19). Ray Anderson on Mike \& Mike: "We are going to protect our players" with stricter enforcement of rules against illegal hits. Retrieved September 1, 2015, from nflcommunications.com: http://nflcommunications.com/2010/10/19/ray-anderson-on-mike-mike$\%$ e2\%80\%9cwe-are-going-to-protect-our-players\%e2\%80\%9d-with-stricterenforcement-of-rules-against-illegal-hits/

NFL Staff. (2010, October 27). Commissioner Goodell speech on protecting youth athletes from concussions sent nationwide by CDC. Retrieved September 1, 2015, from nflcommunications.com:

http://nflcommunications.com/2010/10/27/commissioner-goodell-speech-onprotecting-youth-athletes-from-concussions-sent-nationwide-by-cdc/

NFL Staff. (2010, November 11). USA Football makes rule change, develops injury guidelines to improve player safety. Retrieved September 1, 2015, from nflcommunications.com: http://www.nflcommunciations.com/2010/11/11/usafootball-makes-rule-change-develops-injury-guidelines-to-improve-player-safety/

NFL Staff. (2010, December 9). Univ. of North Carolina doctor on minimizing concussions: "We need to focus on teaching how to tackle appropriately." Retrieved September 1, 2015, from nflcommunications.com: http://nflcommunications.com/2010/12/09/univ-of-north-carolina-doctor-on- 
minimizing-concussions-\%E2\%80\%9Cwe-need-to-focus-on-teaching-how-totackle-appropriately\%E2\%80\%9D/

NFL Staff. (2010, December 16). NFL's Merton Hanks: "Health and safety of an individual player is more important than any game." Retrieved September 1, 2015, from nflcommunications.com:

http://nflcommunications.com/2010/12/16/nfl\%e2\%80\%99s-merton-hanks$\%$ e2\%80\%9chealth-and-safety-of-an-individual-player-is-more-important-thanany-game\%e2\%80\%9d/

NFL Staff. (2011, January 18). Fox's Daryl Johnston: Players need to wear proper padding. Retrieved September 1, 2015, from nflcommunciations.com: http://nflcommunications.com/2011/01/18/fox\%e2\%80\%99s-daryl-johnstonplayers-need-to-wear-proper-padding/

NFL Staff. (2011, March 22). Competition Committee transcript. Retrieved September 1, 2015, from nflcommunications.com:

http://www.nflcommunications.com/2011/03/22/competitions-committeetranscript/

NFL Staff. (2011, April 6). Jeff Pash on negotiations: "We have continuously moved toward their position in an effort to reach an agreement." Retrieved September 1, 2015, from nflcommunciations.com:

http://nflcommunications.com/2011/04/06/jeff-pash-on-negotiations$\%$ e2\% $80 \% 9$ cwe-have-continuously-moved-toward-their-position-in-an-effort-toreach-an-agreement\%e2\%80\%9d/

NFL Staff. (2011, September 6). Commissioner Goodell: "We have to do everything we can to remove HGH from the game." Retrieved September 1, 2015, from nflcommunciations.com:

http://nflcommunications.com/2011/09/06/commissioner-goodell$\%$ E2\% $80 \% 9$ Cwe-have-todo-everything-we-can-to-remove-hgh-from-thegame\%E2\%80\%9D/

NFL Staff. (2011, November 14). NFL, Philadelphia Eagles and Pittsburgh Steelers Commend Pennsylvania Legislature on Senate Bill 200, Aimed at Protecting Young Athletes. Retrieved September 1, 2015, from nflcommunications.com: http://www.nflcommunications.com/2011/11/14/nfl-philadelphia-eagles-andpittsburgh-steelers-commend-pennsylvania-legislature-on-senate-bill-200-aimedat-protecting-young-athletes/

NFL Staff. (2012, May 22). Transcript: NFL EVP Jeff Pash, NFL VP of Player Engagement Troy Vincent \& Falcons President \& CEO \& Competition Committee Chairman Rich McKay at 2012 Spring League Meeting. Retrieved September 1, 2015, from nflcommunications.com:

http://nflcommunications.com/2012/05/22/transcript-nfl-evp-jeff-pash-nfl-vp-ofplayer-engagement-troy-vincent-falcons-president-ceo-competition-committeechairman-rich-mckay-at-2012-spring-league-meeting/ 
NFL Staff. (2012 June 21). Senator Durbin praises NFL for taking action against bounties. Retrieved September 1, 2015, from nflcommuncations.com: http://www.nflcommunications.com/2012/06/21/senator-durbin-praises-nfl-fortaking-actions-against-bounties/

NFL Staff. (2012, July 10). USA Football, 4 NFL Teams Staging Health Clinics. Retrieved September 1, 2015, from nflcommunciations.com: http://www.nflcommunications.com/2012/07/10/usa-football-4-nfl-teams-staginghealth-clinics/

NFL Staff. (2012, August 28). Oliver Luck Joins NFL Player Safety Advisory Panel. Retrieved September 1, 2015, from nflcommunciations.com: http://www.nflcommunications.com/2012/08/28/oliver-luck-joins-nfl-player-safetyadvisory-panel/

NFL Staff. (2012, September 12). NFL Commissioner Roger Goodell, Army Vice Chief of Staff General Lloyd Austin, Reps. Mike Thompson, Gus Bilirakis Join Forces to Tackle Traumatic Brain Injury. Retrieved September 1, 2015, from nflcommunciations.com: http://www.nflcommunciations.com/2012/09/12/nflcommissioner-roger-goodell-army-vice-chief-of-staff-general-Iloyd-austin-repsmike-thompson-gus-bilirakis-join-forces-to-tackle-traumatic-brain-injury/

NFL Staff. (2012, November 20). Video from Player Safety Advisory PanelChampionship Football. Retrieved September 1, 2015, from nflcommunciations.com: http://www.nflcommuncations.com/2012/11/20/videofrom-player-saftey-advisory-panel-championship-football/

NFL Staff. (2012, December 01). Information on NFL's Total Wellness Program for Current \& Former NFL Players. Retrieved September 1, 2015, from nflcommunications.com:

http://www.nflcommunications.com/2012/12/01/information-on-nfls-total-wellnessprogram-for-current-former-nfl-players/

NFL Staff. (2013, January 10). NFL Statement on NIH Finding. Retrieved September 1, 2015, from nflcommunications.com: http://www.nflcommunications.com/2013/01/10/nfl-statement-on-nih-finding/

NFL Staff. (2013, February 27). USA Football to Lead Player Safety on Youth Level Through Heads Up Football Program's Master Trainers. Retrieved September 1, 2015, from nflcommunications.com:

http://www.nflcommunications.com/2013/02/27/usa-football-to-lead-player-safteyon-youth-level-through-heads-up-footbal-programs-master-trainers/

NFL Staff. (2013, March 13). NFL Health and Safety Update - March 13, 2013. Retrieved September 1, 2015, from nflcommunciations.com: http://nflcommunications.com/2013/03/13/nfl-health-and-safety-update-march-132013/

NFL Staff. (2013, April 3). Foundation for the NIH Joins NIH in Seeking Proposals to 
Study Sports-Related Brain Injuries. Retrieved September 1, 2015, from nflcommunications.com:

http://www.nflcommunications.com/2013/04/03/foundation-for-the-nih-joins-nihin-seeking-proposals-to-study-sports-related-brain-injuries/

NFL Staff. (2013, May 1). NFL Health and Safety Update - May 1, 2013. Retrieved September 1, 2015, from nflcommunications.com:

http://nflcommunications.com/2013/05/01/nfl-health-and-safety-update-may-12013/

NFL Staff. (2013, May 22). NFL Health and Safety Update - May 22, 2013. Retrieved September 1, 2015, from nflcommunications.com:

http://nflcommunications.com/2013/05/22/nfl-health-and-safety-update-may-222013/

NFL Staff. (2013, July 3). NFL Health and Safety Update - July 3, 2013. Retrieved September 1, 2015, from nflcommunications.com: http://nflcommunications.com/2013/07/03/nfl-health-and-safety-update-july-32013/

NFL Staff. (2013, July 24). NFL Health and Safety Update - July 24, 2013. Retrieved September 1, 2015, from nflcommunications.com:

http://nflcommunications.com/2013/07/24/nfl-health-and-safety-update-july-242013/

NFL Staff. (2013, August 21). NFL Health and Safety Update - August 21, 2013.

Retrieved September 1, 2015, from nflcommunications.com: http://nflcommunications.com/2013/09/21/nfl-health-and-safety-update-august21-2013/

NFL Staff. (2013, September 4). NFL, Under Armour and GE Seek Ideas to Accelerate Concussion Research, Prevention, Diagnosis \& Treatment. Retrieved September 1, 2015, from nflcommunications.com: http://nflcommunications.com/2013/09/04/nfl-under-armour-and-ge-seek-ideasto-accelerate-concussion-research-prevention-diagnosis-treatment/

NFL Staff. (2013, October 2). NFL Health and Safety Update - October 2, 2013.

Retrieved September 1, 2015, from nflcommunications.com:

http://nflcommunications.com/2013/09/21/nfl-health-and-safety-update-october-22013/

NFL Staff. (2013, October 30). NFL Health and Safety Update - October 30, 2013.

Retrieved September 1, 2015, from nflcommunications.com: http://nflcommunications.com/2013/09/21/nfl-health-and-safety-update-october30-2013/

NFL Staff. (2013, November 20). NFL Health and Safety Update - November 20, 2013.

Retrieved September 1, 2015, from nflcommunications.com:

http://nflcommunications.com/2013/09/21/nfl-health-and-safety-updatenovember-20-2013/

NFL Staff. (2014, January 15). NFL Health and Safety Update - January 15, 2014. 
Retrieved September 1, 2015, from nflcommunications.com:

http://nflcommunications.com/2013/09/21/nfl-health-and-safety-update-january15-2014/

NFL Staff. (2014, January 30). NFL Health and Safety Press Conference. Retrieved September 1, 2015, from nflcommunciations.com:

http://www.nflcommunciations.com/2014/01/30/nfl-health-and-safety-pressconference/

NFL Staff. (2014, February 26). NFL Health and Safety Update - February 26, 2014.

Retrieved September 1, 2015, from nflcommunications.com: http://nflcommunications.com/2013/09/21/nfl-health-and-safety-update-february26-2014/

NFL Staff. (2014, March 26). NFL Health and Safety Update - March 26, 2014.

Retrieved September 1, 2015, from nflcommunications.com:

http://nflcommunications.com/2013/09/21/nfl-health-and-safety-update-march-262014/

NFL Staff. (2014, July 24). 'Heads Up Across America' Premieres Monday, July 28 on NFL Network. Retrieved September 1, 2015, from nflcommunications.com: http://nflcommunications.com/2014/07/24/heads-up-across-america-premieresmonday-july-28-on-nfl-network/

NFL Staff. (2014, September 3). NFL, USA FOOTBALL, Fuel Up to Play 60, and National Recreation and Park Association to Bring NFL FLAG Program to 500,000 Students in Schools and Recreation Centers Nationwide. Retrieved September 1, 2015, from nflcommunications.com:

http://nflcommunications.com/2014/09/03/nfl-usa-football-fuel-up-to-play-60-andnational-recreation-and-park-association-to-bring-nfl-flag-program-to-500000students-in-schools-and-recreation-centers-nationwide/ 